\title{
Histone deacetylation - a new epigenetic target in cancer
}

\author{
João A Carvalho ${ }^{1 * \dagger}$, Emília Cortesão ${ }^{1,2,3 \dagger}$, José D Branco ${ }^{1 \dagger}$, Ana C Gonçalves ${ }^{1,3}$, Sílvia Neves ${ }^{1,3,4}$, Filipa Carvalho ${ }^{1}$, \\ André Ribeiro', Vera Alves ${ }^{1}$, Teresa Silva', Marília Dourado ${ }^{1,3}$, José M Nascimento-Costa ${ }^{1,2,3}$, \\ Ana B Sarmento-Ribeiro 1,3,4
}

From 16th International Charles Heidelberger Symposium on Cancer Research Coimbra, Portugal. 26-28 September 2010

The hypermethylation of the "CpG islands" and histone deacetylation have been considered key epigenetic mechanisms in several types of cancer. Despite hypomethylating agents are already used in the treatment of some subtypes of Myelodysplastic Syndromes (MDS), the role of ,histone deacetylase inhibitors in hematological and solid tumors is still unclear.

With this work we intend to evaluate the potential therapeutic effect of the histone deacetylase inhibitor, Trichostatin A (TSA), in MDS, Chronic Lymphocytic Leukemia (CLL) and in hepatocellular carcinoma (HCC).

For this, the cell lines EHEB (B-CLL), F36P (MDS) and HUH-7 (HCC were maintained in culture in absence and presence of TSA and/or Decitabine (DEC), a demethylating drug. The density and cell viability was assessed using Trypan Blue and/or Alamar test. Cell death was evaluated by flow cytometry using Annexin V and optic microscopy.

Our results show that epigenetic modulators, TSA and DEC, induce a decrease in cell proliferation and viability in a dose, time, administration squeme and cell type dependent manner, inducing cell death by apoptosis. Besides TSA was also more effective in monotherapy, when administered to cells $3 / 4$ hours before than DEC, or in a daily dose it was observed an increase in the cytotoxic effect. On the other hand, MDS seems to be the less sensitive cells and the higher cytotoxic effect is achieved earlier and at lower doses in HUH-7 cells than in EHEB cells, for the same drug concentration.

This study suggests that histone deacetylation may become a new therapeutic approach in cancer. However,

\footnotetext{
* Correspondence: andre_carvalho_7@hotmail.com

† Contributed equally

${ }^{1}$ Faculty of Medicine, University of Coimbra (FMUC), Coimbra, Portugal
}

Full list of author information is available at the end of the article the schedule of drugs administration and cell type may interfere with their therapeutic efficacy.

\section{Author details}

${ }^{1}$ Faculty of Medicine, University of Coimbra (FMUC), Coimbra, Portugal.

${ }^{2}$ University Hospital of Coimbra (HUC), Coimbra, Portugal. ${ }^{3}$ Center for Investigation on Environment, Genetics and Oncobiology (CIMAGO), FMUC, Coimbra, Portugal. ${ }^{4}$ Center for Neuroscience and Cell Biology (CNC),

Coimbra, Portugal.

Published: 24 September 2010

\section{doi:}

Cite this article as: Carvalho et al:: Histone deacetylation - a new epigenetic target in cancer. BMC Proceedings 2010 4(Suppl 2):P60.
Submit your next manuscript to BioMed Central and take full advantage of:

- Convenient online submission

- Thorough peer review

- No space constraints or color figure charges

- Immediate publication on acceptance

- Inclusion in PubMed, CAS, Scopus and Google Scholar

- Research which is freely available for redistribution

Submit your manuscript at www.biomedcentral.com/submit
C Biomed Central 